\title{
The Influence Of Learning Styles On Student Perception And Satisfaction In A Highly Collaborative Team Taught Course
}

Daniel Sullivan, Ed.D., J.D., Ashland University, USA Michael Colburn, Ph.D., Ashland University, USA

Daniel E. Fox, J.D., C.P.A., Ashland University, USA

\begin{abstract}
Team teaching an undergraduate business capstone course has the potential of providing students with an enhanced learning experience in a number of ways. This study examines the relationship between faculty and student learning styles and their impact on student perception and satisfaction in a highly collaborative team taught undergraduate business capstone course. The faculty members as well as students in the control and experimental groups completed Kolb's Learning Style Inventory. Research data revealed that the learning styles of the three member faculty team influenced student perception of course material and their overall level of satisfaction. This study suggests that the diversity of faculty learning styles present in the classroom provides a common connection with groups of students with the same or similar learning style which enhances the learning environment. In addition, the highly collaborative team teaching model created an environment of cohesion and commitment among the faculty members.
\end{abstract}

Keywords: Team Teaching; Learning Styles; Business Capstone

\section{INTRODUCTION}

e n a previous study, the authors (Colburn, Sullivan, and Fox (2012) reported a statistically significant improvement in student learning outcomes with students having a Grade Point Average of 3.28 or less from a team teaching experience. This study examines the underlying reasons for this success in terms of faculty learning styles and relevant work experiences. Research revealed that student satisfaction increases when students sense that faculty members share a learning style similar to their own. Team teaching increases the potential for student-faculty learning style bonding by increasing the number of learning styles present in the classroom. This study also revealed that learning styles influence the manner in which faculty members share previous work experiences with students. The closer the faculty member's learning style resembles that of the students' the greater the understanding standing of the concept being presented.

\section{LITERATURE REVIEW}

The key to successful teaching is choosing the teaching style that best meets the needs of students (McKenna, Yalvac, and Light, 2009). Kember (1997) determined that faculty teaching styles align into two distinct groups; student-centered/learning-oriented and teacher-centered/content-oriented. Faculty preferring a teachercentered style conveys knowledge from a holistic perspective focusing on effective ways to transmit their collective knowledge to students. A student-centered approach differs from the above by focusing on methods to actively engage students in the learning process. Instructors advocating this teaching style strive to change students' perception of course material by appealing to their sensory interpretation of the material and guiding them to a place 
of greater understanding (McKenna, Yalvac, \& Light, 2009). In 2004, Trigwell and Prosser expanded Kember's (1997) work by examining faculty teaching intentions. As a result of their effort, five distinctive teaching styles emerged differentiated by the instructor's overriding intentions:

1. Teacher-focused strategy with the intention of transmitting information to students

2. Teacher-focused strategy with the intention that students acquire the concepts of the discipline.

3. Teacher/student interaction strategy with the intention that students acquire the concepts of discipline.

4. Student-focused strategy aimed at students developing the conceptions.

5. Student-focused strategy aimed at students changing their conceptions.

Trigwell and Prosser (2004) stated that the use of any of the above style varies with the situation and individual. Faculty preferring a particular teaching style may employ different styles throughout the course of a semester in response to student outcomes or course material. Research suggests that student-focused teaching provides the most beneficial learning platform and that relationships exist between exists the faculty teaching style used and student learning outcomes (Mckenna, Yalvac, \& Light, 2009; Prince and Fielder, 2006; Kember and Gow, 1994).

Researchers divide students into three distinct learning categories; deep learners, strategic learners, and surface learners (McKenna, Yalvac, and Light, 2009; Cutbert, 2005; Biggs, 1999; Entwistle and Ramsden 1983). Students in the deep learning category focus their attention on the overall meaning of the subject matter and are more likely to do independent research as a means to enhancing their overall understanding of the material. Strategic learners focus on completing specific tasks in the most efficient manner possible and are motivated by achieving the highest grade possible on exams. Surface learners often display a negative attitude toward learning and are motivated by a desire to pass the course in order to avoid negative consequences. Entwistle (2001) states that students in each learning category can be further classified as active or passive depending upon their level of motivation. Kolb (1984) states that perceiving the student's preference for understanding personal experiences and converting these experiences in to knowledge is critical to the educational process. According to Kolb, learners perceive and process information in the following continuum:

1. Concrete experience: being involved in a new experience

2. Reflective observation: watching others or developing observations about one's own experience

3. Abstract conceptualization: creating theories to explain observations

4. Active experimentation: using theories to solve problems, and make decisions

Kolb (1984), states that individuals develop permanent learning styles as accommodators, divergers, convergers, or assimilators; groupings that closely associate with particular methods of information processing. An accommodating or concrete experience/active experimenter learning style describes individuals who prefer learning through "doing" or "hands-on" experiences. They prefer a practical approach to learning and are often attracted to new challenges and experiences (McLeod, 2010). Accommodaters favor intuition over logic and prefer to perform their own analysis of theories as part of the learning experience. Divergers or individuals preferring a reflective observer/concrete experience learning style are individuals who learn by watching and feeling. Individuals favoring this learning style tend to be imaginative, emotional, and prefer working in groups rather than working alone. Often divergent learners have broad cultural interests and are gifted in the arts (McLeod, 2010). Students favoring a logical approach to learning fall into the group Kolb described as assimilators or abstract conceptualization/reflective observer learners. This type of learner prefers clear explanations and is capable of receiving and understanding a wide range of information. Assimilators relate well to abstract concepts and judge the benefits of learning along a practical continuum. The last learning style advocated by Kolb is called convergers. Convergers or abstract conceptualization/active experimenter learners are individuals favoring the use of technical tasks in the learning process and learn by doing. Convergers prefer finding practical applications for theories and are less concerned with interpersonal aspects of learning (McLeod, 2010).

The problem faculty face is the random compilation of students in the classroom. Students are not assigned classes based upon their compatibility to the instructor's learning style. Any given class may consist of deep, strategic, or surface learners, in active or passive forms, who are influenced by any one of the above four learning 
styles. Selecting a teaching method that reflects positively on all students can be difficult if not impossible for instructors. Often they search for the middle ground among the learning styles present in an effort to provide meaningful instruction to as many students possible (McKenna, Yalvac, \& Light, 2009).

A collaborative team teaching approach is one method faculty can use to available to ensure students receive a meaningful educational experience (Cuthbert, 2005). Team teaching provides faculty with a platform for expanded intellectual resources and larger variety of personal experiences to draw upon to enhance the student's learning experience. It also provides them with the ability to cast a broader net in an effort to engage more students (McKenna, Yalvac, \& Light, 2009; Cuthbert, 2005; Mezirow, 1998; Kolb, 1983).

In higher education, team teaching has taken different forms. One of the most common forms involves mixing the curricula from two or more different courses in an effort to provide students with an enhanced learning experience. When this occurs, the faculty team consists of the representatives from the various disciplines being taught. Typically instructors' have the option of being present for all class sessions or only the ones they themselves teach. In situations where instructors shared the classroom, students' were better able to interconnect key interdisciplinary concepts and witness the benefits of cooperation, team building, and communications through the instructors' behavior (Beck, 2006). Sharing the classroom enabled faculty to avoid redundancy and lay the foundation for interdisciplinary scholarship. Another commonly used form of team teaching emphasizes the cofacilitation of a single subject matter. This technique enables instructors to exploit each other's strengths in the area of study for the benefit of the students and improve their own understanding of the topic. Team teaching of this type provides a forum for faculty to learn from each other (Lester and Evans, 2009). Whatever the form, collaborative team teaching provides instructors the greatest opportunity to encourage learning by reaching the student though his or her core learning style (Shipley, 2006; Helms, Alvis, and Willis, 2005).

\section{RESEARCH QUESTIONS}

This study examines the relationship between faculty learning styles in the design and execution of highly collaborative team taught undergraduate business capstone course. The authors posed the following research question:

a. What impact do student and faculty learning styles have on student perception and satisfaction in a highly collaborative team teaching environment?

b. What are the factors that influence faculty satisfaction and effectiveness in a highly collaborative team teaching environment?

\section{METHODOLOGY}

Data were collected from students in three sections of undergraduate business capstone courses. The experimental class, designated as Section B, was taught using a three person team teaching model. All three faculty members participated in the design and execution of this course. The faculty team participated in a number of work sessions over a three-month period to design the course. Course topics were divided among the faculty team based on interests and expertise. A common format for lesson plans was agreed upon and used by each member. Lesson plans for Section B were designed to follow a Student-Focused format and enable students to perceive and process information using Kolb's learning continuum. Student engagement was the primary focus of the lesson planning process. Plan designs were revised for effectiveness based on feedback and suggestions from other team members. Assessments, grading rubrics and the grading system for the course were co-designed. Team members shared the course load by taking the lead in key course content delivery areas. One faculty member assumed the role of technology leader and maintained the Angel Course Management System. Another assumed the lead on the web based business simulation used throughout the semester and the other was "current events" leader for the study. The current events leader ensured that course material effectively represented existing trends within the business community. Students were encouraged to communicate with any or all of the faculty members throughout the course. 
The other two sections, designated as Sections $\mathrm{A}$ and $\mathrm{X}$, were designed and taught by a single faculty member, using a Teacher-Focused format. The classes were taught in a tradition lecture format designed to transmit information to the students. Of the 69 students enrolled in the combined three sections, 50 chose to participate in the study: 25 students in the experimental class and 25 students from sections A \& X. All students and faculty participating in the study completed Kolb's Learning Style Inventory. The inventory were scored and tabulated after the course ended.

At the conclusion of the course all students, Sections A, B, \& X, completed a standard student satisfaction questionnaire. Students in the control group completed only this research instrument. Students in the experimental class (Section B) completed two additional instruments. First, they rated a series of statements provided by the researchers using a 5 point Likert scale. A rating of 1 signified strongly disagreement and 5 signified strongly agree with the statements provided. The following three statements were evaluated by the participants in the survey:

1. "The material covered by the different faculty team members was well integrated."

2. "Team teaching provided me with diverse insights into the course content."

3. " "The team teaching method provided me with a valuable learning experience."

Second, students in the experimental group were required to provide a written response to the following open ended question: "Please discuss one or more things that worked for you in this team taught course?" All student data was collected by impartial parties and placed in sealed envelopes until final course grades were entered. Student identifiers were removed by administrative assistants before the data were given to the researchers for evaluation. The faculty team (researchers) did not know which students chose to participate, or their responses to the various research instruments until all grades had been posted. Survey instruments were designed to enable the researchers to gather data on the following response and explanatory variables:

\begin{tabular}{|c|c|}
\hline Response Variables & Explanatory Variables \\
\hline $\begin{array}{l}\text { Student } \begin{array}{l}\text { Outcomes: } \\
\text { Student satisfaction through the analysis } \\
\text { of the student survey and responses to } \\
\text { open-ended questions. }\end{array} \\
\text { Faculty Outcomes: } \\
\text { Faculty satisfaction through the analyses } \\
\text { of responses in in-depth interviews at the } \\
\text { conclusion of the course }\end{array}$ & $\begin{array}{ll}\text { Students: } \\
\circ & \text { Learning style as measured by Kolb's } \\
& \text { LSI assessment } \\
\text { Faculty: } & \\
\circ & \text { Previous experience with team teaching } \\
\circ & \text { Previous experience working in a team } \\
& \text { environment } \\
\circ & \text { Learning Style as measured by Kolb's } \\
& \text { LSI Assessment }\end{array}$ \\
\hline
\end{tabular}

\section{RESEARCH RESULTS}

\section{Students and Faculty's Learning Styles:}

Research data revealed that learning styles influence student perception of course material and their overall level of satisfaction in a highly collaborative team teaching environment. Faculty as well as students in the control and experimental groups completed Kolb's Learning Style Inventory. The learning style inventory results were tabulated by an independent third party and revealed to the researchers after the course had ended. Chart 1 shows the plot of the learning styles for the students in the control group and the individual faculty member who taught these sections. The faculty member responsible for teaching the control group sections tested in the Accommodator learning style category. Data revealed that few students in the control group shared the instructor's learning style. As a result, the instructor was forced to adjust his natural teaching style to accommodate the learning styles of his students. Members of the control and experimental groups evaluated their learning experience using a common student satisfaction instrument. Overall student satisfaction among members of the control was 4.1 on a 5 point Likert scale. 
Chart 1 Student and Faculty Learning Styles for the Control Group

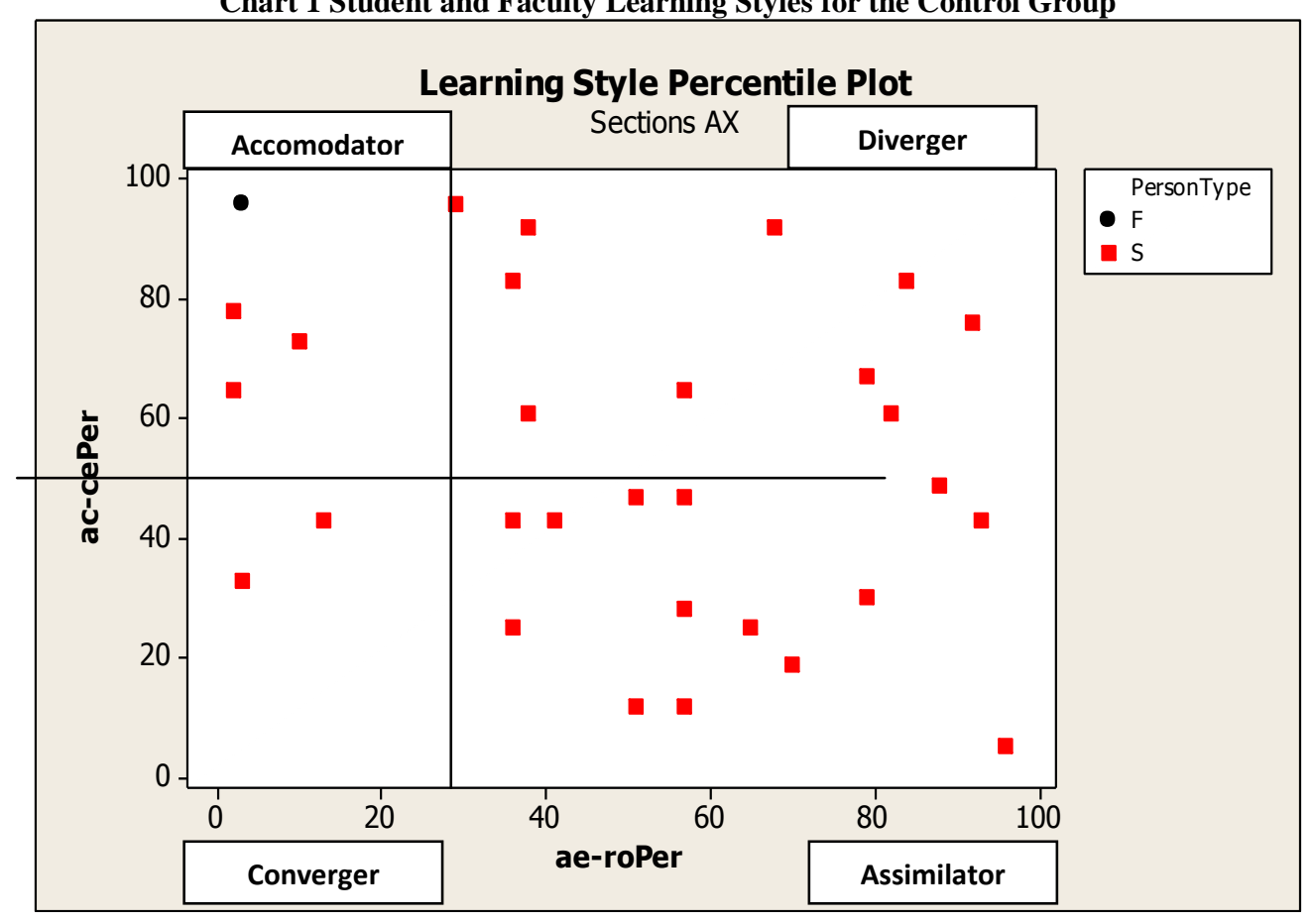

Chart 2 Student and Faculty Learning Styles for the Experimental Group

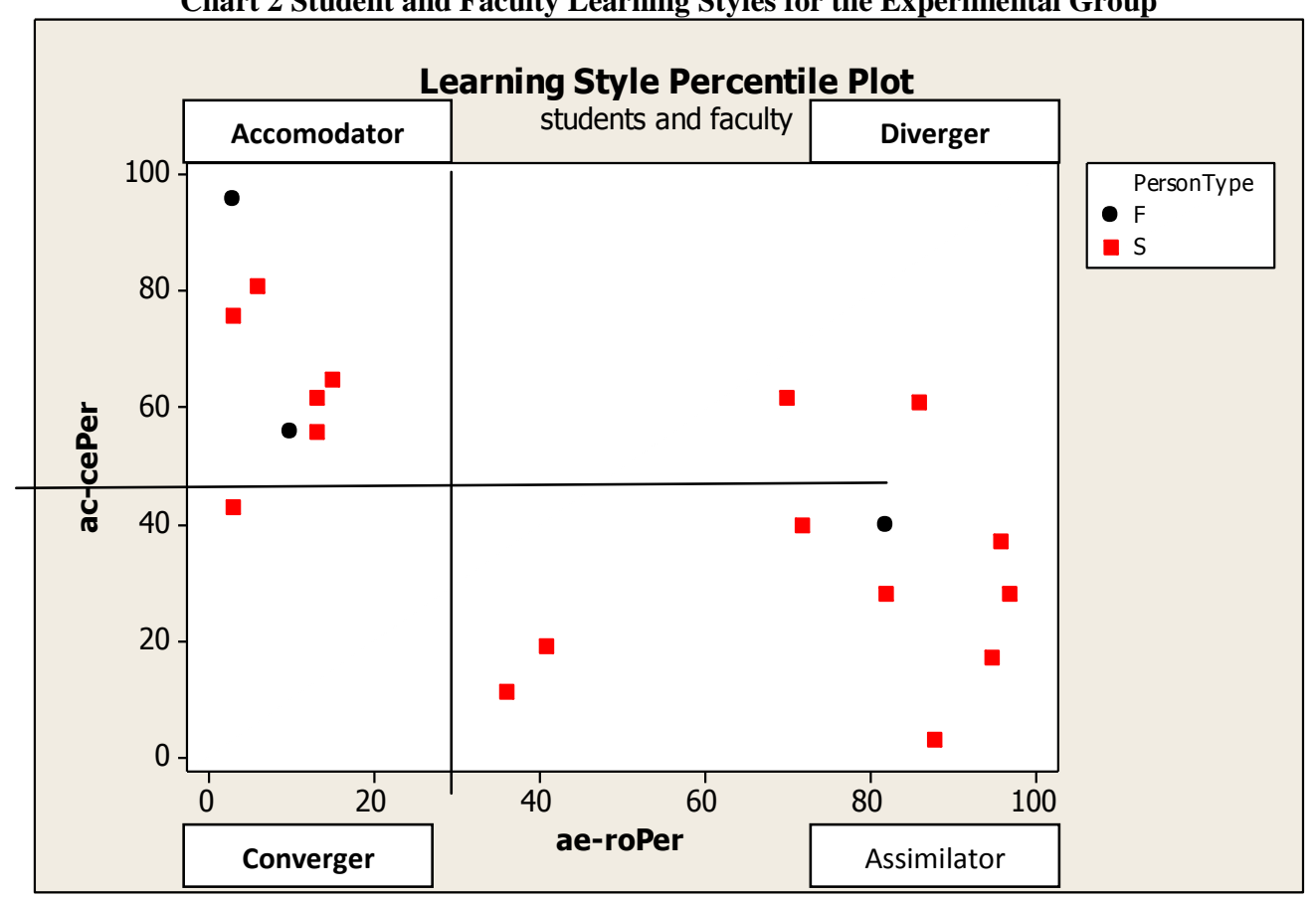

Chart 2 shows the learning style plot for the students in the experimental group plotted with the styles of the faculty team. Two major learning style clusters emerged from the data. At the upper left hand of the chart there was a cluster of students and two faculty members with an Accommodating learning style. Accommodating learners favor learning through concrete experiences and active experimentation. A cluster of similar learning styles also appears in the lower right hand quadrant of the chart. This concentration of student was more comfortable with an assimilating teaching style emphasizing reflective observations and abstract conceptualization. One faculty member 
shared this learning style. Overall student satisfaction for the experimental group measured 4.6 on a 5 point Likert scale; a one half point increase over that the control group. Survey data suggests that overall satisfaction was enhanced because students related well to at least one of the professor's teaching styles.

Participants in the experimental group were asked to evaluate three statements regarding their experience using a 5 point Likert scale (Chart 3). Question 1 was designed to measure student satisfaction with the various disciplines brought to the classroom by the faculty. Survey data revealed that students were very satisfied with the level of diversity present in the classroom. Statement 1 scored 4.74 out of 5 indicating that students in the experimental group valued diversity in the classroom above all other team teaching experiences. Students in the experimental group also indicated that they believed the course material to be well integrated (Statement 2).

Chart 3. Supplemental Satisfaction Evaluation by Experimental Group

\begin{tabular}{|l|l|l|}
\hline$\#$ & Likert Rating & Highly Collaborative Team Teaching Aspect \\
\hline 1 & 4.74 & Team teaching provided me with diverse insights into the course content \\
\hline 2 & 4.47 & The material covered by the different faculty team members was well integrated \\
\hline 3 & 4.42 & The team teaching method provided me with a valuable learning experience \\
\hline
\end{tabular}

Students stated that the faculty's broad array of disciplines improved the transition between course topics and that their explanations went way beyond those typically provided by instructors. Statement 2 scored 4.47. Statement 3 was designed to measure the value students placed on their team taught experience. Students indicated that the variety of disciplines present in the classroom allowed them to better understand the need for a capstone experience and its value to the curriculum. Statement 3 scored 4.42 indicating a level of importance $.3+$ points higher than the overall satisfaction level of the control group.

Three themes emerged from student responses to the open-ended question "What are one or more things that worked in this team taught course?" The first theme to emerge was student enjoyment for "Multiple Insights" on the material being taught. Students expressed their appreciation for the various ways the course material was used throughout the team members' business careers. Practical applications of strategic theory were emphasized by the facility team. Team exercises illustrated how a single theory can be given varying applications depending upon the management discipline involved. Team members were able to answer student questions using their various backgrounds and experiences as points of reference.

Theme two centered on the students' appreciation for the "Diversity of Opinions" present in the classroom. Often faculty team members disagreed with the real-world value placed on the material presented. Faculty team members' backgrounds varied from financial, manufacturing, law, engineering, and consulting (Chart 4). Classroom discussion captured these varying opinions. Students indicated they were stimulated by the variety of the discussion and enjoyed the debate offered by the instructors. They also stated that it was the debate that seduced them to engage in the conversation. Students enjoyed the depth of understanding provided by faculty on topics that exposed the rational, implications, and politics behind complex business relationships. They especially appreciated advice on how to avoid common mistakes and pitfalls as new employees. Experimental group students felt that the diversity of opinions present in the class added to the course content. The final theme to emerge was "Use of Learning Styles". Students stated that the different teaching methods used by the faculty team kept things interesting. They also stated that they appreciated the presence of a faculty member they could relate to in the classroom. Their presence provided them a zone of comfort that enhanced learning.

\section{FACULTY SATISFACTION}

At the conclusion of the team taught course, all three members of the team were interviewed by a faculty member from the University's College of Education. The purpose of these interviews was to gain insights on how the team teaching experience impacted the faculty team. One major conclusion from the interview was the high level of satisfaction each faculty team member had with the team teaching experience. Five themes (Chart 5) emerged from the interview process regarding team teaching. The first theme to emerge was that successful team teaching requires a common motivation among team members. They must be jointly committed to improving the overall quality of the course. Two of the three faculty members had previously taught the capstone course and were 
familiar with student concerns with the individual instructor experience. The third faculty member had not taught the class before but was experienced in collaborative instruction. One of the main objectives of the collaboration was to provide students with a classroom experience with the feel of being a newly hired employee. Assignments were designed to replicate the types of requests given to new hires and evaluated from an employer's point of view. Students were provided with strategic tools commonly used in business to complete these assignments. Assignments were graded in terms of career consequences and the opportunity to develop a long term relationship with an employer.

The second theme to emerge was the need for positive cohesion and commitment. Redesigning the capstone course to convey a feeling of an employee/employer relationship required a "clean sheet" approach to course design. At the beginning of the course-redesign process, the faculty team members had different experiences, ranging from positive to negative, with previous team teaching experiences. Developing a new team taught capstone experience required team members to push aside past biases and approach the project with a fresh perspective. As obstacles appeared, they were dealt with promptly and through a predefined process. This provided each team member due process for their concerns and kept the focus on improving the course instead of airing individual differences. The process afforded each team member the opportunity to lead part of the planning process and appreciate the progress being made in the redesign. Team members commented that the mix of similarities and differences created an atmosphere, during the planning process that was fun, energizing, and focused.

Chart 4. Faculty Team Background and Roles

\begin{tabular}{|c|c|c|c|}
\hline & Faculty Member 1 & Faculty Member 2 & Faculty Member 3 \\
\hline $\begin{array}{l}\text { Class Sections } \\
\text { Taught }\end{array}$ & $\begin{array}{l}\text { Control Group } \\
\text { Experimental Group }\end{array}$ & Experimental Group & Experimental Group \\
\hline $\begin{array}{l}\text { Previous Team } \\
\text { Teaching } \\
\text { Experience }\end{array}$ & $\begin{array}{l}\text { Positive experience team teaching } \\
\text { engineering capstone courses at } \\
\text { another university. Positive } \\
\text { experiences team teaching training } \\
\text { courses in industry. }\end{array}$ & $\begin{array}{l}\text { Mixed experiences with } \\
\text { team in an introduction } \\
\text { business course. }\end{array}$ & $\begin{array}{l}\text { Generally negative experiences } \\
\text { team teaching } \quad \text { with } \\
\text { management/union teams in } \\
\text { industry. }\end{array}$ \\
\hline Business Experience & $\begin{array}{l}\text { Ten years' experience as an } \\
\text { industrial engineer and industrial } \\
\text { engineering manager with three } \\
\text { manufacturing companies. Over } 25 \\
\text { years experiences as a business } \\
\text { consultant to a variety of businesses. }\end{array}$ & $\begin{array}{l}\text { Five years experience } \\
\text { practicing tax and general } \\
\text { business law. Seven years } \\
\text { of entrepreneurial startup } \\
\text { experience. Five years of } \\
\text { international business } \\
\text { consulting experience. }\end{array}$ & $\begin{array}{l}33 \text { years of experience in a } \\
\text { variety of upper level } \\
\text { management upper positions at a } \\
\text { major manufacturer. Significant } \\
\text { experiences include; Finance, } \\
\text { Engineering, Manufacturing, } \\
\text { Facility Management, and } \\
\text { Quality. }\end{array}$ \\
\hline $\begin{array}{l}\text { Teaching } \\
\text { Experience }\end{array}$ & $\begin{array}{l}\text { Adjunct faculty in engineering and } \\
\text { business colleges. } \\
\text { Regular faculty member for six } \\
\text { years in a business college }\end{array}$ & $\begin{array}{l}\text { Adjunct faculty member at } \\
\text { the MBA level for } 14 \\
\text { years. Director of } \\
\text { Entrepreneurship and } \\
\text { Associate Dean for } 5 \text { years. } \\
\text { Regular faculty member for } \\
\text { five years. }\end{array}$ & $\begin{array}{l}5 \text { years' experience as a faculty } \\
\text { member, regular and adjunct, } \\
\text { teaching entrepreneurship, law, } \\
\text { labor relations, and operations } \\
\text { management. }\end{array}$ \\
\hline $\begin{array}{l}\text { Education and } \\
\text { Professional } \\
\text { Certification }\end{array}$ & $\begin{array}{l}\text { Bachelor of Industrial Engineering } \\
\text { M. S. in Industrial and Systems } \\
\text { Engineering. } \\
\text { Ph.D. in Adult Education } \\
\text { Registered professional engineer }\end{array}$ & $\begin{array}{l}\text { Bachelor of Arts in } \\
\text { Accounting and Political } \\
\text { Science. } \\
\text { Jurist Doctorate } \\
\text { Licensed Attorney } \\
\text { Certified } \\
\text { Accountant }\end{array}$ & $\begin{array}{l}\text { Bachelor of Science in } \\
\text { Economics \& Accounting } \\
\text { MBA } \\
\text { Jurist Doctorate } \\
\text { Ed.D. in Organizational } \\
\text { Leadership }\end{array}$ \\
\hline $\begin{array}{l}\text { Learning Style } \\
\text { (Kolb) }\end{array}$ & $\begin{array}{l}\text { Accomodator } \\
\text { - AC-CE ( } 96 \text { percentile) } \\
\text { - AE-RO ( } 3 \text { percentile) }\end{array}$ & $\begin{array}{l}\text { Accommodator } \\
\text { - AC-CE ( } 56 \text { percentile) } \\
\text { - AE-RO ( } 10 \text { percentile })\end{array}$ & $\begin{array}{l}\text { Assimilator } \\
\text { - AC-CE ( } 40 \text { percentile }) \\
\text { - AE-RO ( } 82 \text { percentile })\end{array}$ \\
\hline $\begin{array}{l}\text { Emergent Team } \\
\text { Role }\end{array}$ & $\begin{array}{l}\text { Project Manager } \\
\text { Business Simulation Lead }\end{array}$ & $\begin{array}{l}\text { Technology Lead } \\
\text { Financial Analysis }\end{array}$ & $\begin{array}{l}\text { Current Events Lead } \\
\text { Student Attendance Lead }\end{array}$ \\
\hline
\end{tabular}


The third theme to emerge was that similarities and differences in the professional experiences of the faculty team members actually enhanced course design. Lesson plans were critiqued on a variety of professional levels. All three faculty members spent most of their careers in different aspects of the business world; working in management roles, consulting, and/or running their own businesses. They had worked frequently in a team environment and were heavily involved in change initiatives in a number of organizations. Interview analysis revealed that each team member had gained an appreciation and tolerance for diverse opinions before the course design phase began. These experiences provided the faculty team with tools to collaborate, initiate change, and to manage conflicts throughout the study.

\begin{tabular}{|l|l|}
\multicolumn{1}{l}{ Chart $\mathbf{5}$} \\
\hline No. & Theme \\
\hline 1 & There was a common motivation to improve the quality of the course. \\
\hline 2 & The diversity of the team was a positive force for cohesion and commitment. \\
\hline 3 & The similarities in the professional experiences of the faculty team provided tools to manage the change process \\
\hline 4 & Collaboration in the design and implementation of the course created a culture of shared meaning. \\
\hline 5 & Each faculty member experienced professional development in the implementation of the course. \\
\hline
\end{tabular}

The fourth theme to emerge was the need for collaboration in the design and implementation of the course. Learning activities and assessment instruments were jointly developed. Team members reviewed and critiqued lesson plan developed by module leaders. Plans changes were discussed and jointly agreed upon. The spirit of collaboration provided much need energy to the planning process. Team members stated they were motivated by the desire not to fail a fellow team member. The final theme to emerge from the interviews was the realization that each team member was growing academically from the experience. Each faculty member stated that they experienced growth and professional development in the implementation of the course. As course topics were being developed, team members gained a new appreciation of the background and experiences of other team members. They also developed a deeper understanding of the course material. The planning process enabled team members to engage in long meaningful discussions that clarified misunderstandings and provided a more complete analysis of topics. As the experience unfolded, the faculty members enjoyed the camaraderie and class response. In the post course interviews, the faculty members indicated that they enjoyed attending and engaging in class discussions when they were not the lead instructor. They reported that these class sessions were fun and energizing.

\section{CONCLUSION}

This study suggests that the diversity of learning styles present in the classroom enhances student satisfaction. Study results confirmed the effectiveness of using a Student-Focused teaching style in a team taught environment. Overall student satisfaction among the control group experiencing a teacher-focused teaching style measured a 4.1 on a 5 point Likert scale. Satisfaction among the students in the experimental group taught the same course material using a student centered approach, measured 4.6 on the same scale; a full half point higher than the control group. Student feedback revealed that the higher satisfaction levels experienced by the experimental group were related to the team teaching approach for delivering course material. Students enjoyed the multiple insights and diverse opinions of the faculty. They especially liked seeing how the different learning styles present in the classroom fit their individual needs. As discussed in an earlier publication (Colburn, Sullivan, \& Fox, 2012), the impact of team teaching on Kolb's learning continuum using a Student-Focused team teaching approach proved most effective among students with a GPA of less than 3.28.

This study suggests the need for harmony and collaboration among faculty members engaged in team teaching. The classroom is a stage and the instructors, even in a Student-Focused environment, are key players. Students focus their attention on the behavior of the instructors for cues on the importance of course material and group dynamics. Instructors enjoying their team teaching experiences are projecting lessons of proper behavior, etiquette, and ethics. They are creating an environment of comfort and learning for their students. The value students perceive from these displays of behavior is apparent in their positive evaluation of the team teaching experiences.

Finally, the study suggests that the random student assignment process used by many institutions influences the learning environment. Random class assignment places the student and instructor in compromising positions. In 
our study, the control group was taught by a single instructor with an Accommodator learning style. Through random assignment, $75 \%$ of the student in the class were force to compromise there natural learning style to participate in and pass the class. Conversely, the instructor had to teach out his comfort zone to reach $75 \%$ of his students. The effectiveness of this compromise on both parties is a subject for future study. Students in the experimental group experienced a different learning environment. Only $25 \%$ of these students were unable to connect directly with an instructor sharing their natural learning style. Study data suggest that students value these direct connections and perform better when they are present in the classroom. Although it may be impractical for institutions to assign students to classes based upon their potential match to the instructor's learning styles, it does suggest the need for instructors to know the learning styles of students present in their classrooms and raises the question of whether learning style assessment should be part of the student admissions process.

\section{AUTHOR INFORMATION}

Daniel Sullivan, Ed.D., J.D. Assistant Professor of Business Management, Ashland, University, Ashland, Ohio 44805 E-mail: dsulliv1@ @ashland.edu (Corresponding author)

Michael Colburn, Ph.D. Assistant Professor of Business Management, Ashland University, Ashland Ohio 44805 E-mail: mcolburn@ashland.edu

Daniel E. Fox, J.D., C.P.A. Associate Professor of Law, Ashland, University, Ashland, Ohio 44805 E-mail: dfox1@ashland.edu

\section{REFERENCE LIST}

1. Beck, A. (2006). Adventures in team teaching: Integrating communications into an engineering curriculum. Teaching English in a Two Year College, 34(1), 59-70.

2. $\quad$ Biggs, J. (1999). Teaching for Quality Learning at University. Buckingham: SRHE and Open University Press.

3. Cohen, M.B., \& DeLois, K. (2001). Training in tandem: Co-facilitation and role modeling in group course work. Social Work with Groups, 24(1), 21-36.

4. Colburn, M., Sullivan, D.W., \& Fox, D.E. (2012, March). An examination of the impact of team teaching on student learning outcomes and student satisfaction in undergraduate business capstone courses. American Journal if Business Education, 5(2), 149-158.

5. Cutbert, P.F. (2005, April). The student learning process: Learning styles or learning approaches?. Teaching in Higher Education 10(2), 235-249.

6. Entwistle, N.J. (2001). Styles of learning and approaches to studying in higher education. Kybernetes, 30(5/6), 593-602.

7. $\quad$ Entwistle, N.J., \& Ramsden, P. (1983). Understanding Student Learning. London: Croom Helm.

8. Helms, M.M., Alvis, J.M., \& Willis, M. (2005, September/October). Planning and implementing shared team teaching: An MBA team-teaching case study. Journal of Education for Business, 29-34.

9. Kember, D. (1997). A reconceptualisation of the research into university academics. Concepts of teaching. Learning and Instruction 7 (3):255-75.

10. Kimber, D. \& Gow, L. (1994). Orientations to teaching and their effect on the quality of the student learning. Journal of Higher Education 65(1), 58-74.

11. Kolb, D.A. (1984). Experimental Learning. Englewood Cliffs, New Jersey: Prentice-Hall.

12. Lester, J.N.\& Evans K.R. (2009). Instructors' experiences of collaboratively teaching: Building something bigger. International Journal of Teaching and Learning in Higher Education, Vol. 20, \#3, Pgs.373-382.

13. McLeod, S. (2010). David Kolb - Learning Styles. Retrieved on June 21, 2012 from http://www.simplypsychology.org/learning-kolb.html

14. McKenna, A.F., Yalvac, B., \& Light, G.J. (2009, January). The role of collaborative reflection on shaping engineering faculty teaching approaches. Journal of Engineering Education, 17-26.

15. Mezirow, J. (1998). On critical reflection. Adult Learning Quarterly, 48(3), 185-198

16. Prince, M.J., \& Fielder, R.M. (2006). Inductive teaching and learning methods: Definitions, comparisons, and research bases. Journal of Engineering Education 95(2), 123-138. 
17. Shibley, I.A., Jr. (2006). Interdisciplinary team teaching: Negotiating pedagogical differences. College Teaching, 54(3), 271-274.

18. Trigwell, K, \& Prosser, M. (2004). Development and use of the approaches to teaching inventory.

Educational Psychology Review 16(4), 409-424. 